\title{
Beliefs associated with Food Production Methods
}

\author{
Reimar von Alvensleben, Institute for Agricultural Economics, University of Kiel
}

\begin{abstract}
In: Frewer, L.J., Risvik, E., Schifferstein, H. (Eds.): Food, People and Society - A European Perspective of
\end{abstract} Consumer's Food Choices. Springer-Verlag Berlin Heidelberg New York 2001, P. 381-400.

\section{Introduction}

Increasing use of modern technologies in agriculture and food production and market saturation in affluent societies have led to a growing consumers' interest in the methods used to produce food. More and more consumers pay attention not only to the product quality but also to the processes used in manufacture ("process quality"). They would like to know more about how their food has been produced. Many consumers are concerned about the production methods in modern agriculture and in the food industry. Against this background it is important to know how consumers perceive the production methods: What are public beliefs associated with the food production of today? What are the determinants of these beliefs and how do they affect consumer behaviour?

\section{Beliefs associated with agricultural production methods in general}

An appropriate method to measure salient beliefs is the association test, which can be applied in different ways in order to understand consumer beliefs about food production methods for instance by asking the question: "What is on your mind, when you hear the word ....?" We applied this test in a small sample $(n=30)$ using different stimuli such as "Animal husbandry"(table 1), "Poultry keeping", "Plant protective agents" (table 2) and "fertilizers".

\section{Table 1: Spontaneous asssociations with the stimulus "Animal husbandry"}

1. Positive (3): free-range, happy hens (2) - keeping animal free range

2. Neutral (17): Hopefully "animal friendly" (artgerecht) - should be kept naturally - breeding beasts - hens cows (4) - cows on a pasture - keeping dairy cows - rearing cows and pigs - pigs (2) - geese - stable fertilizer - there are good and bad aspects to it.

3. Negative (40): exploitation - factory farming (9) - keeping masses of animals - mass production - animal factories - cows side by side in giant sheds - too small stables - too confined - confined - not "animal friendly" (3) - rarely "animal friendly" (2) - natural animal husbandry rather rare - too many medical drugs - animals stuffed with drugs - too much concentrated feed stuff - unhealthy - pity for the animals nowadays cruel - nowadays often terrible - cruel to animals (2) - unworthy of animals - unhealthy animals - hospitalism - animals bitten to death - fidgeting hens - squeaking pigs in a lorry - stench - utmost precaution.

Numbers in brackets refer to how frequently items were mentioned

Source: Sies and Mahlau (1997), p. 15 (results)

The answers to the stimulus "Animal husbandry" give an impressive picture of salient beliefs associated with the modern livestock production: Out of 60 associations only 3 have been positive, 17 could be regarded as neutral and 40 were clearly negative: Most of these negative associations were related to animal welfare aspects of production. Results for the stimulus "Poultry keeping" were similar. According to research results in other European countries, the widespread negative perception of modern animal husbandry seems to be similar across different European countries. 
A similar set of beliefs was associated with crop production (table 2). Using the stimulus "Plant protective agents" only 10 associations could be categorized as positive or neutral and 50 as negative. The original answers indicate the widespread latent concerns associated with the application of chemistry in modern crop production. Similar, but slightly less negative results have been obtained for the stimulus "fertilizers".

\section{Table 2: Spontaneous associations with the stimulus "Plant protective agents"}

1. Positive (5): good, if applied moderatly - much grain - necessary to survive - partly necessary (2)

2. Neutral (5): can be viewed positive and negative - spraying equipment (2) - spraying.

3. Negative (50): poison (8) - chemistry (2) - pesticides (4) - E 605 - insecticides - poisened food - dangerous (4) - be careful (2) - risk of overapplication (2) - better less application and smaller harvest overfertilization - to much - should be applied less - should become more expensive, then less application unhealthy (3) - causing illness of men (3) - causing malformations - harmful (2) - unnatural - monoculture - pollution of the environment (6) - poor plants - sick trees (2) - destroying the soil - objection - terrible farmers acting too much in good faith - resistance? - expensive.

Numbers in brackets refer to how frequently items were mentioned

Source: Sies and Mahlau (1997), p. 6 (results)

However, not all agricultural production methods are perceived in such a negative way. According to other consumer surveys conducted in 1989 and 2000 in Germany there is a wide variability of the acceptance of agricultural technologies (table 3 ).

Table 3: Beliefs associated with agricultural technologies 1989 and 2000

(Scale: $1=$ much more disadvantages, $3=$ midpoint, $5=$ much more advantages)

\section{Average Score}

1989

2000

Free range pork production

Milking machine

Conventional plant breeding

Organic agriculture ("Alternativer Landbau")

Conventional animal breeding

Automatic feeding systems

Artificial fertilizer ("Mineraldünger")

Automatic milking systems ("Melkroboter")

Genetechnology in plant breeding

Chemical plant protection

Genetechnology in animal breeding

Vegetable production without soil

$\begin{array}{cc}. & 4.5 \\ 4.1 & 4.3 \\ 4.0 & 4.2 \\ 4.2 & 3.9 \\ 3.4 & 3.6 \\ 3.1 & 3.4 \\ 2.6 & 3.2 \\ . & 3.0 \\ 2.9 & 2.4 \\ 1.9 & 2.2 \\ \cdot & 2.1 \\ 2.6 & .\end{array}$

Source: Institute for Agricultural Economics, University of Kiel: Consumer surveys in Hannover and Kiel $1989(n=326)$ and in Kiel $2000(n=270)$

In the opinion of most of consumers, perceived disadvantages are associated with the application of plant protective agents, genetechnology in plant and animal breeding and 
vegetable production without soil (1989). In the case of artificial fertilizer ("Mineraldünger"), automatic milking systems ("Melkroboter"), and automatic feeding systems in animal husbandry, perceived advantages and disadvantages are almost equal. Other technologies, such as conventional animal and plant breeding, milking machines, but also organic farming and free range pork production are perceived to be advantageous by the majority of the respondents. Comparing the results of the two surveys, public acceptance of gene technology and organic agriculture seem to have declined between 1989 and 2000, while the scores of all other technologies improved slightly.

These results can be generalized as follows (von Alvensleben and Steffens, 1990):

- Technologies applied to plants are more accepted than technologies applied to animals.

- Mechanization is more accepted than agricultural chemistry

- Old, well known technologies (combine harvester, milking machine) are more accepted than new technologies (automatic feeding systems, automatic milking systems).

- Conventional breeding is more accepted than genetic engineering.

- "Natural" production methods (organic farming, free range animal husbandry) are more accepted than "high-tech" agriculture and food technology.

What are the determinants of negative attitudes towards modern agricultural production methods? In the literature reliable results on causalities are rare. Some of the hypotheses that have been generated include the following (von Alvensleben, 1998): Consumer negativity is

- A consequence of market saturation in an affluent society (Maslow),

- Caused by a decreasing basic trust in the institutions/authorities of the society, including institutions regulating consumer protection,

- Due to an increasing alienation of consumers from agricultural and food production - as a consequence of the division of labour in the economy,

- The result of distorted perceptions,

- Amplified by negative media reports about modern agriculture and food technologies.

One of the consequences is a considerable consumer concern about food, which may have an effect on consumer behaviour. In the subsequent section of this chapter we discuss beliefs associated with organic food, free range livestock products, functional food and genetically modified foods (GM foods). On a scale of perceived naturalness consumers may rate these foods as follows:

\section{Perceived naturalness of food}

Natural

unnatural

Organic food/Free range Conventional food $\quad$ Functional food $\quad$ GM food

Source: Jonas and Beckmann, 1998, p. 19 - modified 


\section{Beliefs associated with organic food}

Consumers' uneasiness about modern agricultural production methods has been important in the development of the organic food market. In an association test conducted as a part of a consumer survey $(\mathrm{n}=2000)$ in Germany 1999 , respondents associated the stimulus "Bioproducts" first of all with absence of chemical applications, natural production, caring animal husbandry and the health value of the products (table 4). The majority of the answers were related to the production method, rather than to the product. Negative associations were rare (3.2\%). A similar pattern of response applied to the association "expensive" (5.7\%).

\section{Table 4: Associations with the stimulus "Bio-products" in \%}

\begin{tabular}{|lc}
\hline 1. Without chemicals & 29.0 \\
2. Natural products, natural & 19.4 \\
3. Without artificial fertilizer & 17.7 \\
4. "Biological" farming & 13.1 \\
5. Healthy/more healthy & 10.6 \\
6. "Ecological" farming & 9.0 \\
7. Caring animal husbandry & 8.7 \\
8. Not sprayed & 8.0 \\
9. Environment friendly & 5.9 \\
10. Expensive & 5.7 \\
11. No pesticides & 5.4 \\
12. Controlled farming & 4.8 \\
13. Not containing noxious agents & 4.8 \\
14. Not genetically manipulated & 4.7 \\
15. Natural manure, dung & 4.3 \\
16. Free range animals (hens) & 3.5 \\
17. Negative associations & 3.2 \\
Bio-Products unknown & 5.2 \\
& \\
Note: The term "organic" farming is rarely used in Germany & \\
\hline
\end{tabular}

In a longitudinal study we asked respondents to rank different motives when buying organic food. These motives were presented to the respondents in a list. Table 5 shows the distribution of the first order rankings for the years 1989, 1994 and 1999. The predominant motive is "health" (64\% of the first order rankings), followed by "ecological aspects" (12\%), "better taste" $(9 \%)$, the chemical residual aspect $(8 \%)$ and curiosity $(6 \%)$. There are no differences between frequent buyers of organic produce compared to occasional buyers. These findings correspond to the results of numerous other studies in Germany and other countries (see the literature reviews of Plöger, Fricke and von Alvensleben, 1993, and of Schifferstein and Ophuis, 1998). They are also consistent with the fact that consumer concerns about chemical residuals in food as well as environmental consciousness in Germany have declined in the nineties. Consumers are increasingly interested in the assumed health value when buying organic produce. 


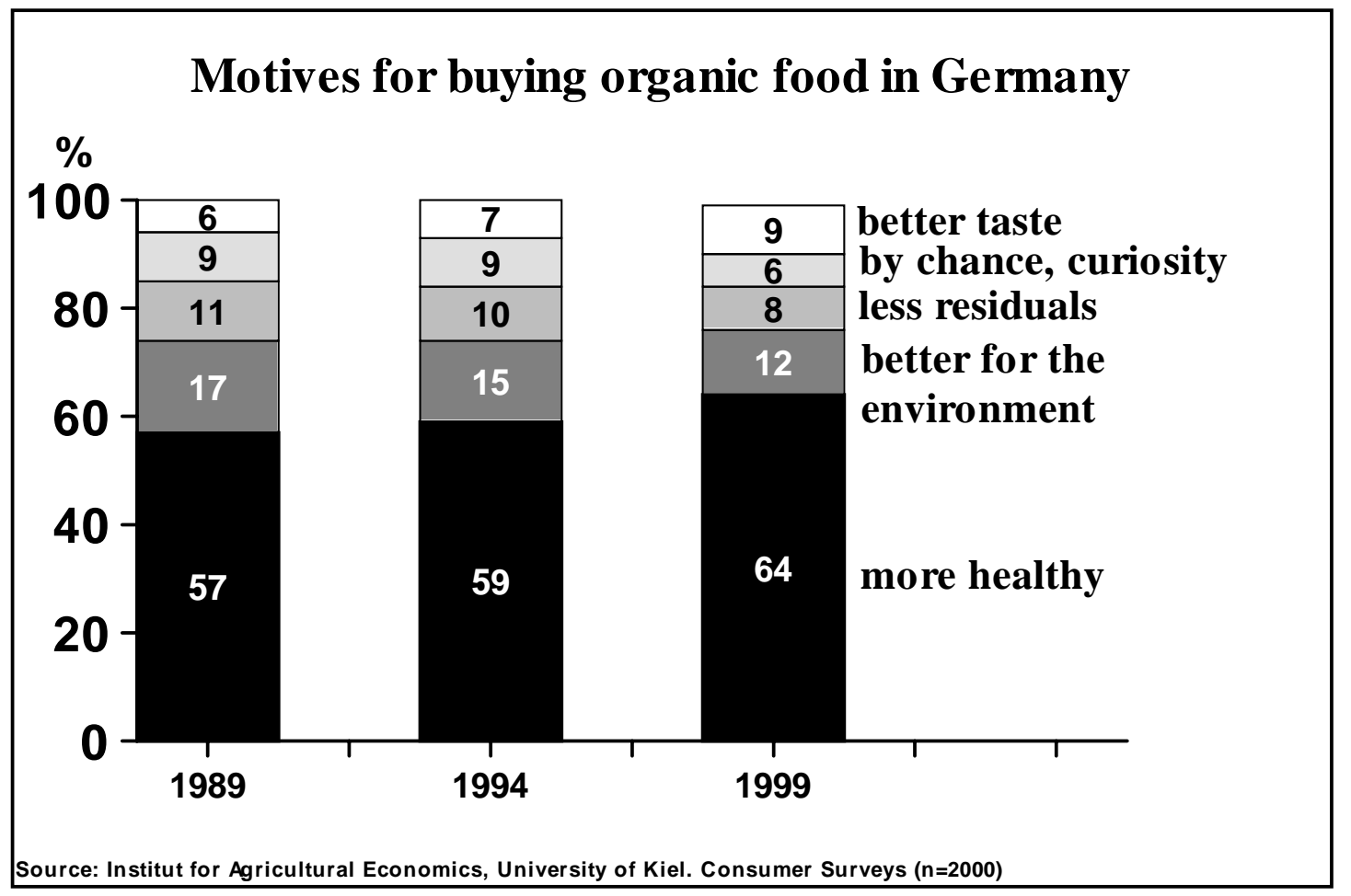

In the Netherlands Schifferstein and Ophuis (1998) found that organic food buyers considered themselves more responsible for their own health, and were more likely to undertake preventive health action than the general population. Wholesomeness, absence of chemicals, environment friendliness, and better taste were the primary reasons for buying organic foods. They also measured a range of life-style variables of the respondents and concluded that the differences between buyers and non-buyers on a multitude of measures suggest that organic food consumption is part of a way of life. It results from ideology, connected to a particular value system, that affects personality measures, attitudes and consumption behaviour.

In Germany "ideological consumers" were an important segment of the organic food market during the eighties. However, several studies indicate that their market share is declining and that they have become a minority within the organic food buying sector. The Sinus-Institute (1995) conducted a lifestyle segmentation study of customers of health and natural food stores in Germany. About $27 \%$ of them were classified as "alternative" consumers. The majority (44\%) were "technocratic-liberal", $14 \%$ "hedonistic", $6 \%$ "conservative" and $10 \%$ other consumer groups (Röder, 1997). A more recent study by the same institute suggested a further decline in the "alternative" segment. According to a recent study in Germany (Bruhn, 2000) the major growth of the organic food demand occurs within the older and well established groups of the population. Their consumption of organic food is primarily associated with health considerations, and is rarely part of a wider lifestyle. If this continues, organic food will be marketed as a health food, particularly for older people, who may be more concerned about the health aspects of food choice.

In a study on organic pork in the United Kingdom, Denmark, and Finland Arvola (1998) investigated the cross cultural differences in the beliefs and buying intentions. The majority of respondents believed that animal welfare and food safety would improve if they bought organic pork. It was believed to contain no added chemicals, and to be more expensive and healthier than conventional pork. Respondents in Denmark had consistently more negative 
beliefs about organic pork than respondents in Finland and the UK, whereas Finnish respondents were always more positive about organic pork. Danish consumers were especially concerned about the authenticity of the "organic" claim, and the British about food safety and expense.

In Germany a multiple regression analysis examining the relationship between attitudes/beliefs and (self reported) consumption for organic food revealed the major determinants of the demand for organic food. Relative importance of attitudes on food choice has changed considerably between 1984-1999 (table 6):

Table 6: Multiple regression of the organic food demand with the attitudes/beliefs (Beta-coefficients)

\begin{tabular}{|c|c|c|c|c|}
\hline Independent variables & 1984 & 1989 & 1994 & 1999 \\
\hline Better quality of organic food & 0.14 & 0.14 & 0.21 & 0.24 \\
\hline Health consciousness & 0.24 & 0.26 & 0.23 & 0.20 \\
\hline Convenience & -0.06 & -0.18 & -0.09 & -0.20 \\
\hline Confidence in conventional food & -0.31 & -0.33 & -0.23 & -0.19 \\
\hline Shopping atmosphere & $\mathbf{0 . 0 8}$ & 0.11 & 0.13 & 0.14 \\
\hline Organic food only a fashion & -0.17 & -0.11 & -0.14 & -0.11 \\
\hline Willingness to pay for quality & 0.13 & 0.09 & 0.16 & 0.11 \\
\hline Positive purchase experience & 0.15 & 0.14 & 0.15 & 0.06 \\
\hline $\mathbf{R}^{2}$ & 0.23 & 0.29 & 0.22 & 0.24 \\
\hline
\end{tabular}

While in the eighties distrust in the conventional food supply was the major driving force for organic food demand, belief in the better properties of the organic products became the most important determinant in the nineties. Another important factor which has had a positive effect on organic food consumption was the health consciousness of the consumer, as well as distrust in conventionally produced food, the desire for a good shopping atmosphere and the willingness to pay for quality. Consumers prefering convenience food are less likely to consume organic food. The same applies to consumers who believe the organic food consumption to be a temporary fashion.

After a rapid increase up to 1994, the self-reported organic food consumption in Germany remained static during the last five years. We divided the total sample into four segments according to buying frequency for organic products: Non-buyers, occasional, medium and frequent buyers. Table 7 shows the shares of these types over the observed period. 
Table 7: Buyer types for organic food in Germany: 1984-1999

in \%

\begin{tabular}{lcccc}
\hline Buyer type & 1984 & 1989 & 1994 & 1999 \\
\hline Frequent buyers & 5 & 12 & 15 & 18 \\
Medium buyers & 21 & 29 & 43 & 35 \\
Occasional buyers & 21 & 22 & 18 & 21 \\
Non-Buyers & 53 & 37 & 25 & 26 \\
Source: Bruhn (2000): Consumer surveys $(n=2000)$ & & \\
\hline
\end{tabular}

The share of frequent buyers increased from 5\% (1984) to $18 \%$ in 1999, the share of medium buyers increased from $21 \%$ (1984) to $43 \%$ (1994) and subsequently declined to $35 \%$ (1999), the percentage of occasional buyers remained the same in the observed period, while the share of non-buyers declined from $53 \%$ (1984) to $25 \%$ (1994) and remained almost the same during the last five years. Most probably respondents tend to overestimate their consumption frequency, however it is not known, whether this overestimation bias remained constant over the total period. Since the actual market development showed a further market growth, there is some indication that the overestimation bias declined during the final period. One of the possible reasons for the change of answering behaviour may be, that organic food consumption is becoming more habitual - a normal part of shopping.

At the same time the willingness to pay a price premium for organic food, which increased rapidly in the eighties in Germany, showed a slight decline during the nineties. The average accepted price premium developed as follows (Bruhn, 2000):

$\begin{array}{ll}\text { 1984: } & 13 \% \\ \text { 1989: } & 21 \% \\ \text { 1994: } 20 \% \\ \text { 1999: } 18 \%\end{array}$

These results suggest that the market growth during the last years has not primarily been driven by the demand side, but was mainly caused by activities of the supply side:

- Declining prices (as a consequence of the increasing supply, which was partly stimulated by the governmental subsidy programs)

- Increasing distribution density (more selling points, more sales by the supermarkets, etc.)

- Product diversification and better product quality

- Intensified communication (advertising, sales promotion, public relations).

If this is true, the future development of the organic food market will depend heavily on the intensity and quality of the marketing activities of the suppliers.

\section{Beliefs associated with free-range livestock products}

The determinants of the demand for organic food are closely related to those for free-range livestock products. As already mentioned, organic food is often associated with higher animal 
welfare standards. If people are asked how they define "animal welfare", the most frequent answers are "free range" production and similar terms. The majority of consumers believe that free-range livestock products have superior properties, in particular that they are healthier and taste better - despite the fact that taste differences between free range and battery produced eggs have never been proven in taste trials.

These beliefs are not new: In a study conducted 1973 in the German town of Göttingen, $79 \%$ of respondents agreed with the statement: "Eggs taste better from farmers who still keep chickens naturally." In 1987 Will and Balling found a similar support of the statement "One gets the tastiest meat from free range animals" in the Bavarian town of Freising. In a more recent study in Kiel more than $80 \%$ of the test persons agreed with the statements "Free range eggs taste good" and "Free range eggs are good quality." In a conjoint analysis Renken (1997) found the production method to be the most important factor determining consumer preferences for eggs. Price and colour of the eggs were of less importance. Ceteris paribus, free range eggs were preferred by $85 \%$ of the test persons, barn eggs by $12 \%$ and battery eggs only by $3 \%$. In another survey in Kiel $59 \%$ of the respondents were interested in buying free range pork, while only $18 \%$ said it may be to fatty and expensive. (von Alvensleben et al, 1997). In Ireland, focus group discussions revealed that free range eggs as well as free range chickens are supposed to have a different and better taste (Cowan, Meehan and Winkless, 1998, p. 8, 14). The majority $(77 \%)$ of the Irish consumers regarded "free range" as an indicator of food safety. In Italy, $73 \%$ of the customers of a supermarket offering free range eggs thought that these eggs are different from the others, $47 \%$ consider them different with respect to quality, and $21 \%$ with respect to freshness (Miele and Parisi, 1998). In the Netherlands, Ophuis (1994) conducted sensory evaluation tests of free range and regular pork meat. He found that labelling and prior experience with the products do influence sensory evaluation of free range pork favourably for a number of attributes. He compared this result with the findings of brand studies, where the perception of quality was affected by brand image, especially for brands with strong positive images. The attribute "free range" can have the same impact on the perception of product quality as a positive brand image.

Despite the widespread belief in the better quality of free range eggs, chicken and pork, their market share is still very low. This discrepancy between attitude and behaviour is partly due to the higher prices of these products. In the case of free range pork and chicken it is also due to the very limited availability of the products. However, consumer surveys indicate a "willingness to pay" a price premium for free range eggs (table 8):

Table 8: Willingness to pay for free range eggs in different European countries in $\%$ of the sample

\begin{tabular}{lccccr}
\hline Country & Germany & UK & France & Italy & Spain \\
\hline Willingness to pay more & 79 & 77 & 60 & 57 & 78 \\
$1-20 \%$ more & 42 & 35 & 33 & 37 & 57 \\
$25-35 \%$ more & 20 & 17 & 16 & 12 & 10 \\
$40-50 \%$ more & 8 & 12 & 7 & 5 & 9 \\
$55 \%$ and more & 8 & 13 & 6 & 4 & 3 \\
& & & & & \\
Source: Deutscher Tierschutzbund, 1998, & p. & 4, MORI & Social Research Institute, & 1998, \\
$n=1000$ in each country &
\end{tabular}




\section{Beliefs associated with functional food}

As already pointed out, on a scale of perceived naturalness (natural - unnatural) functional foods are positioned between conventional food and genetically modified food. Numerous definitions of the term "functional food" exist. After reviewing these definitions Jonas and Beckmann (1998, p. 2) suggested the following definition: "Functional foods can be described as representing a food category in which the products are either a) modified or b) fortified with substances that have a preventive or therapeutic effect beyond their nutritional value." Foods fortified with vitamins, minerals, and antioxidants are included, but dietary supplements in the form of powder and tablets are excluded in this definition. The English Nutrition Foundation provided the definition that "functional foods are ascribed a potency greater than foods consumed principally for particular nutrient features (health foods), but less than assumed for products classified as medicines" (InterSect Alliance Inc., 1996 - cited by Jonas and Beckmann, 1998, p. 2). Definitions such as these retain the somewhat fuzzy boundaries between "functional" and "traditional" foods.

Indeed, the limits between health food, functional food and medicines/pharmaceuticals are fluid. For this reason functional foods are sometimes called nutraceuticals. As a consequence it is possible that the boundaries between the food industry and the pharmaceutical industry will become blurred. The following example shows, how functional food is positioned between the traditional nutritious food, health food and medicine (table 9):

Table 9: Positioning functional food

$\begin{array}{ccccc}\begin{array}{c}\text { Normal } \\ \text { food }\end{array} & \begin{array}{c}\text { Nutritious } \\ \text { food }\end{array} & \begin{array}{c}\text { Health } \\ \text { food }\end{array} & \begin{array}{c}\text { Functional } \\ \text { food }\end{array} & \text { Medicine }\end{array}$

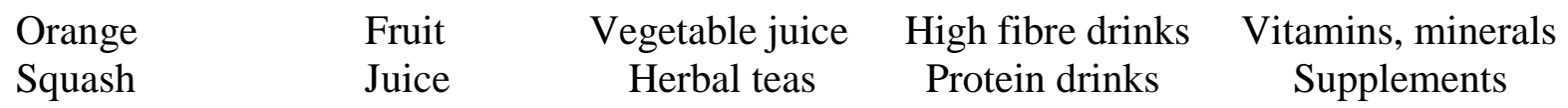

Source: Jonas and Beckmann (1998, p. 1), Potter (1991)

How do consumers perceive these new technological developments in food production? There are only few studies available and they show ambigous results. According to Hilliam (1996, p. 193) there is a strong belief "that what one eats can influence one's health". There is also a belief that such foods will help consumers to live longer and avoid particular medical conditions, provided that the claims made for functional foods are true. Consumption of functional foods may also provide a psychological benefit that arises from a sense of doing something for oneself. Functional foods tend to be perceived as a more "natural" way of achieving health benefits compared to traditional medicine, and as less likely to produce negative side effects. In a consumer survey in the UK, more than two-thirds of the respondents reacted positively to the concept of functional foods. Only $9 \%$ of the respondents felt that it was a bad idea. This percentage was higher among the 65+ age group.

However, Hilliam (1996) also discussed the potential drawbacks of functional foods for consumers. The major question is about the efficacy of functional foods, and about how that efficacy can be assessed. Many consumers believe that the concept of functional foods could be used as a marketing ploy to justify making food more expensive. Other concerns are 
associated with whether functional foods are necessary if one is already eating a healthy diet, whether they are "logical" (Why not simply reduce the consumption of unhealthy food?), and whether they may lull consumers into a false sense of security and be used to compensate for otherwise poor dietary habits.

Jonas and Beckmann (1998) applied laddering in two samples ( $\mathrm{n}=20$ each) in Denmark and the UK. Consumers in Denmark are much more sceptical about the concept of functional food than consumers in the UK. Danish respondents expressed a strong reluctance associated with the modification and fortification of foods, which they regarded as unnatural and impure. The dominating opinion was that a varied diet, perhaps supplemented with vitamin pills, was a much better way to meet nutritional needs. A very different view was revealed by the English respondents. Functional foods were for them a convenient way to meet the requirements of a healthy diet. These findings are consistent with those of Hilliam (1996). They seem to point at cultural differences in the perception of food and diet.

In Germany Potratz (1999) conducted a qualitative study based on in-depth interviews of consumers $(\mathrm{n}=12)$. Most of the respondents reacted positively to the statement "Health can be eaten" as did the majority of the UK consumers. Many of them believed that functional foods could help against nutritional deficits, could be good for the digestion, could prevent illness and were in general healthy products. However, these positive attitudes are mixed with doubts about the efficacy of the claimed positive effects, especially among the elderly respondents. These findings were consistent with the UK results, too. Similar to the Danish consumers some of the German respondents are indicating some concern about the artificial and chemical character of functional foods. They would like to have these foods as natural as possible.

A quantitative study conducted by forsa (1997) in Germany found that more than $50 \%$ of the respondents sampled, claimed to have bought or intended to buy food fortified with vitamins or fibre. Most of them are willing to pay a higher price for such fortified products. The highest interest in functional food was found among younger consumers. In another study on probiotic milk products in Germany, $61 \%$ of the respondents said that this new food technology made sense, $28 \%$ regarded it as useless and $11 \%$ did not know what probiotic cultures were. Again the younger respondents showed a greater interest (GFK, 1998). This result seems to be in line with the general observation that older people tend to be more sceptical regarding new technologies and new products than younger people (neophobia).

In a more recent study Poulsen (1999) investigated Danish consumers' attitudes towards functional food through focus groups, a conjoint analysis and a quantitative survey based on the theory of reasoned action. The focus group interviews revealed that the participants had very little knowledge of functional foods, and were fairly sceptical. However, attitudes to concrete examples of functional foods were much more positive than attitudes to the concept of functional foods. In the quantitative analysis two concrete, but non-existent examples of functional foods were investigated, a dairy product and a bread product, each of which has been enriched with three different substances: (1) soluble food fibre (2) omega-3, and (3) calcium and vitamin $\mathrm{D}$. The conjoint analysis showed that some people were interested in enrichment of food. However, the preferences depended on the kind of product and substances added to the product. If added substances are perceived as natural components of the products, i.e. fibre in the case of bread or calcium in the case of the dairy product, the acceptance of enriched foods was much higher than if this was not the case. In the multiple regression analysis the attitude towards purchasing the respective products has been explained mainly by the perceived convenience of getting the enrichment substance through the daily 
diet (42\% of the explained variation), the price $(21 \%)$, the perceived naturalness of the enriched products $(18 \%)$ and the perceived positive health effect of eating the enriched rather than the conventional product (14\%).

Overall, acceptance of functional food appears to depend mainly on its perceived convenience, naturalness, expected health effects and the price/benefit ratio. These attributes vary between products and the type of manipulation of the product. Since the consumers' knowledge about the attributes of functional foods is still rather limited, the willingness to buy and to pay a higher price will be influenced heavily by the communication from the suppliers and the possible counter-communication from other groups in the society (for example non-governmental organizations).

\section{Beliefs associated with GM food}

It is possible that genetically modified foods have been studied more than any other form of food production. Genetically modified foods have been the focus of risk perception research (See Frewer and Miles, this volume) and theoretical speculation (final chapter, this volume). Whilst there appears to be some similarities in consumer perceptions between GM foods and other aspects of food production, some aspects of consumer concern may be unique to the hazard domain. Some recent studies are briefly reviewed in this chapter. The reader is referred to chapters $\mathrm{x}$ and $\mathrm{xx}$ for further discussion of the importance of trust in information sources and risk regulators, and increased transparancy in regulatory practice, which may also be important in understanding European negativity to GM food.

An association test conducted as part of the Eurobarometer study 52.1 in 15 EU member states gives a first indication of the public beliefs about genetically modified foods (table 10):

Table 10: "What comes to mind when you think about modern biotechnology in the broad sense, i.e. including genetic engineering"?

\begin{tabular}{lc}
\hline & $\%$ \\
\hline Answer category & \\
\hline & 43 \\
Animal cloning and human beings & 33 \\
Scientific research - health - technological development & 28 \\
Genetically modified food & 16 \\
Ethical and philosophical questions & 8 \\
The environment & 28 \\
Don't know & \\
\hline Source: Eurobarometer 52.1 (2000),p.9
\end{tabular}

Both intra-individual and cross-cultural differences in attitudes were observed. For example, evaluations of GM food in Europe tend towards the negative. There is a broad difference of opinion throughout the member states with regard to GM food, with some countries viewing it optimistically, and other pessimistically. The Netherlands, Belgium, Finland, and Sweden 
scored above the European average, while Greece, Luxembourg, Ireland and UK provide the lowest averages.

Eurobarometer has also demonstrated that biotechnology and genetic engineering belong to the group of technologies which will not believed to improve the living conditions by the majority of people confirming the results of other research. Only nuclear energy is rated worse. In addition, while the attitudes to the other technologies have remained rather stable between 1996 and 1999, the ratings of biotechnolgy and genetic engineering declined in the same period.

What are the perceptions of the various applications of biotechnology? Seven applications have been assessed within the Eurobarometer study 52.1 with respect to usefulness, risks, moral acceptability, and whether or not the development should be encouraged. Compared to other applications, the use of modern biotechnology for the production of food is perceived as having the lowest usefulness, the highest risks, the lowest moral acceptability and should be encouraged the least. The application of gene transfer in crop production received similar negative evaluations by the majority of the respondents, while the medical applications were assessed much more favourably at the time of data collection.

Overall, in comparison to the survey results of 1996, the public support of modern biotechnology declined considerably. Only the risk assessment did not change very much. It is notable that the decline of support happened to the medical applications as well as to the agricultural and food applications of biotechnology.

In Germany a study of the perceived benefits, risks and the consumers' acceptance of twelve different products produced by genetic engineering arrived at similar results. The test persons were asked to rate the products on a seven-point scale. For each product they received half a page information about genetic modification of the product (Schütz, Wiedemann and Gray, 1999). The perceived benefits and risks were found to be correlated: The higher the perceived risks the lower are the perceived benefits. Medical products were believed to be associated with more benefits and less risks than food products. These findings confirm the results of other studies (e.g. Gaskell, 1997, Hampel et al, 1997).

Within the Eurobarometer study 52.1 respondents were asked to rate a set of 13 statements concerning GM food on a five point scale. The statements and the average scores are shown in a descending order in table 11:

Table 11: Attitudes towards GM foods in the EU - average scores -

(Scale: $5=$ totally agree, $3=$ midpoint, $1=$ totally disagree)

Statement

Score

Even if GM food has advantages, it is basically against nature

GM food threatens the natural order of things 
GM food is simply not necessary

The idea of GM food causes me great alarm

Even if it means doing without some of its advantages,

GM food should be introduced in a more progressive manner

Whatever the risks involved in GM food, we can avoid them if we really want to

GM food will benefit many people

Of all the risks we have to face at the moment, that of GM food is rather insignificant

If a majority of people were in favour of GM food, it should be permitted

Taking a decision on the issue of GM food is so complicated

that it is a waste of time to consult the public on this subject

The risks involved in GM foods are acceptable

GM food presents no danger to future generations

Source: Eurobarometer 52.1 (2000), p.49/50

A clear majority agrees to the first five statements, which are critical against GM foods. These products are believed to be against nature, risky, simply not necessary and causing great alarm. The reverse statements are rejected by the majority of the respondents. However, a small majority agrees to the statements "Whatever the risks involved in GM food, we can avoid them if we really want to" and "Even if it means doing without some of its advantages, GM food should be introduced in a more progressive manner". Eurobarometer also reported consumer negativity towards behavioural intentions regarding GM food.

Many of the present examples of GM foods are perceived to have no direct benefits for consumers. Why should the consumer expose himself to a risk when there is no benefit for him? The benefit of GM food is believed to remain solely with the industry. Even a lower price will not convince the majority of the consumers. In a series of conjoint analysis experiments with different GM food items in Germany it was found that the utility disadvantage of GM food corresponds to an average price equivalent of 30-40\% (Gath and von Alvensleben, 1998). This means that the prices for GM food must be 30-40\% lower than the prices for competing products, to compensate their utility disadvantage for a significant proportion of the consumers. The distribution of these price equivalents shows that some consumers will accept GM food at a lower price difference, however other consumers will not accept GM food even as a gift. To get a wider acceptance of GM food, it is necessary to offer products that are either substantially cheaper or have other specific and desirable benefits for the consumer (see also Deliza and Mcfie, this volume). 
What are the determinants of the attitudes and the purchase intentions with regard to GM food? Within an EU project conducted in Denmark, Germany, Italy and the UK Bredahl (1999) applied two quantitative models to answer this question: an attitude model and a purchase intention model. The products investigated were fictitious: a yoghurt promising a health benefit and a beer promising an environmental and a price benefit.

Attitudes towards genetic modification in food production were deeply embedded in more general attitudes held by the consumers, in particular their attitude towards nature and attitude towards technology. These general attitudes were found to influence attitudes towards genetic modification through their impact on perceived risks and benefits of the technology. There seem to be differences between countries: In Denmark, Germany and the UK, perceived risks of applying genetic modification in food production in themselves prevented the perception of benefits. In Italy the impacts of perceived risks and benefits on attitudes were independent.

Purchase intentions towards the two product examples were almost exclusively determined by the attitudes towards purchasing the products. These were, in turn, influenced by the overall attitudes towards genetic modification in food production through their effects on beliefs that consumers hold about the quality and trustworthiness of the products.

These results confirm again that the consumers' acceptance of GM food is low, however there are cross-cultural differences: The aversion against GM food was most pronounced in Denmark and Germany. The importance of perceived risks was lower in Italy than in the other three countries. However, as the comparison of the two Eurobarometer studies in 1996 and 1999 shows, these differences are not stable over the time.

Bredahl (1999) concluded that the strong links between attitudes towards genetic modification in food production and higher order attitudes and knowledge domains suggest that attitudes towards GM foods have been established, despite their lack of basis in actual product experience. Likewise, the strong relation of product-specific attitudes to overall attitudes towards genetic modification in food production suggests that at present consumers tend to reject the technology overall rather than to consider products on a case-by-case basis.

All studies indicate that the consumers' knowledge about the application of biotechnology in food production is rather low. For instance, $35 \%$ of the Europeans agree to the statement "Ordinary tomatoes do not contain genes, while genetically modified tomatoes do" (Eurobarometer 52.1, 2000, and Eurobarometer 46.1, 1997). Genes are believed to be something like noxious agents contaminating our food. In Austria a newspaper headline reading "Keep Austria Gene Free" was found during the mobilisation phase of the "Anti Gene-Technology" peoples initiative in spring 1997 (Lehner, 1998, p. 33). This low knowledge raises the question whether the acceptance of GM food is primarily an information and education problem as has been suggested by some researchers (for instance: Hoban, 1997).

However many authors of recent studies are sceptical about the possibilities to increase the consumers' acceptance of GM food by information and education of the consumer (Chess, 1998, Scholderer, 1998, Gath and von Alvensleben, 1998, Bredahl, 1999, Frewer et al, 2000). According to Hampel and Renn, 1998, more knowledge of the scientific basis of the application of modern biotechnology in the food production does not lead to a higher acceptance of GM food, but to a more pronounced judgement which may be either more positive or more negative. Indeed, the relationship between information provision and purchase intention seems to be more complex than the assumption that the low acceptance of 
GM food is due to the fact that consumers simply do not understand the truth about risks and benefits of food technologies (Frewer et al, 2000).

\section{Summary and conclusions}

An increasing number of consumers pay attention not only to the product quality but also to the methods of food production, the so called "process quality" of food:

1. Many consumers are concerned about the production methods in modern agriculture and in the food industry. Especially the application of agricultural chemistry in crop production and modern animal husbandry ("factory farming"“) are perceived negatively by a broad majority of the population. On the other hand well known, familiar technologies (combine harvester, milking machines) and "natural" production methods are viewed much more positive. On a scale of the perceived naturalness (natural - unnatural) different food categories can be positioned in the following order: Organic food and free range livestock products - conventional food - functional food - genetically modified foods (GM foods).

2. Consumers' uneasiness about the modern agricultural production methods has been the major driving force of the emergence of the organic food market. Organic food is associated first of all with absence of chemical applications, natural production, caring animal husbandry and the health value of the product. The predominant motive for buying organic food is the health aspect, followed by ecological aspects. The impact of ideology as a determinant of the demand for organic food is declining. If this continues, organic food will be marketed more and more as a health food for older people. The future development of the organic food market will depend heavily on the intensity and quality of the marketing activities of the suppliers.

3. The determinants of the demand for organic food are closely related to those for freerange livestock products. The majority of consumers believe that free-range livestock products are healthier and taste better - despite the fact, that taste differences between eggs from different production systems have never been proven in taste trials. As in the case of organic food the market share of free range livestock products is still very low. This discrepancy between attitudes and behaviour is partly due to the higher prices of these products. In the case of free range pork and chicken it is also due to the very limited availability of the products.

4. The consumers' acceptance of functional food depends heavily on the perceived naturalness of the product in relation to other product attributes. At present, consumers have very little knowledge of functional foods and are fairly sceptical. However, attitudes towards concrete examples of functional foods may be much more positive. Altogether, the major factors determining their acceptance are the perceived convenience, naturalness, expected health effects and the price/benefit ratio. These attributes vary between products and the type of manipulation of the product. The perception of new functional foods will be influenced heavily by the communication from the suppliers and the possible countercommunication of other groups from the society.

5. In the case of GM food a very low knowledge and a widespread scepticism is found among the public. These products are believed to be against nature, risky, simply not necessary and the causing great alarm. The main problem is that - contrary to most of the medical applications of genetechnology - in all food product examples an obvious 
advantage for the consumer does not exist. Why should the consumer expose himself to a risk when there is no benefit for him? The benefits of GM food are believed to remain solely with the industry. To get a wider acceptance of GM foods, it is necessary to offer products that are either substantially cheaper or have other specific and desired benefits for the consumer. The possibilities to increase the consumers' acceptance of GM food by information and education of the consumer seem to be very limited. More knowledge does not lead to a higher acceptance of GM food, but to a more pronounced positive or negative judgement.

\section{References}

von Alvensleben, R. (1998): Ecological aspects of food demand: The case of organic food in Germany. AIR-CAT $4^{\text {th }}$ Plenary Meeting: Health, Ecological and Safety Aspects in Food Choice. Volume 4, Nr. 1, 68-79.

von Alvensleben, $\boldsymbol{R}$. (1998): Risikowahrnehmung des Verbrauchers: Woraus resultiert die Verunsicherung? (Risk perception of the consumer: What is causing the concern?) Schriftenreihe des Bundes für Lebensmittelrecht und Lebensmittelkunde e.V., Heft 127, 28 43.

von Alvensleben, $\boldsymbol{R}$. et al. (1997): Problems of meat marketing. Seven essays. Lehrstuhl für Agrarmarketing. Institut für Agrarökonomie, Universität Kiel, Arbeitsbericht Nr. 2, 50 p.

von Alvensleben, R., Steffens, M. (1990): Akzeptanz der Ergebnisse technischer Fortschritte durch die Verbraucher - empirische Relevanz. (Consumer acceptance of the results of technological progress - empirical relevance). In: Technischer Fortschritt in der Landwirtschaft - Tendenzen, Auswirkungen, Beeinflussung -. Schriften der Gesellschaft für Wirtschafts- und Sozialwissenschaften des Landbaus e.V., Band 26. Münster-Hiltrup, 233240 .

Arvola, Anne (1998): Beliefs and purchase intentions concerning organic pork in United Kingdom, Denmark, and Finland. AIR-CAT $4^{\text {th }}$ Plenary Meeting: Health, Ecological and Safety Aspects in Food Choice. Volume 4, Nr. 1, 80-82.

Bredahl, L. (1999): Explaining consumer attitudes and behavioural intentions with regard to genetical modified foods - Results of a cross-national study. The Aarhus Business School, Working Paper No 69.

Bredahl. L., Grunert, K.G., Frewer, L. (1998): Consumer attitudes and decision making with regard to genetically engineered food products. - A review of the literature and a presentation of models for future research. The Aarhus Business School, Working Paper No 52.

Bruhn, Maike (2000): Consumer survey $(n=2000)$, still unpublished manuscript.

Chess, C. (1998): Fearing fear. Communication about agricultural biotechnology. AgBioforum, Vol 1, No 1, 5p.

Cowan, C., Meehan, H., Winkless, B. (1998): Consumer concerns about animal welfare and the impact on food choice: Ireland - Literature Review. EU FAIR-CT98-3678, 32 p. 
Durant, J., Bauer, M.W., Gaskell, G. (eds) (1998): Biotechnology and the public sphere. A European resource book. London, 308 p.

European Commission (1997): European opinions on modern biotechnology. Eurobarometer 46.1. Brussels, $87 \mathrm{p}$.

European Commission (2000): The Europeans and Biotechnology. Eurobarometer 52.1. Brussels, 84 p.

forsa (1997): Die Deutschen und ihre Ernährung - was werden wir übermorgen essen? (The Germans and their nutrition - what will we eat tomorrow?). Im Auftrag der LohmannStiftung.

Frewer, L., Shepherd, R., Sparks, P. (1994): Biotechnology and food production: knowledge and perceived risk. British Food Journal, Vol 96, 26-32.

Frewer, L., Scholderer, J., Downs, C., Bredahl, L. (2000): Communicating about risks and benefits of genetically modified foods: Effects of different information strategies. The Aarhus Business School. Working Paper No 71, 48 p.

GFK (1998): Lactobacillus auf Erfolgskurs (Lactobacillus on success course). Pressedienst, 25.9.1998, Nürnberg.

Gaskell, G. et al. (1997): Europe ambivalent on biotechnology. Nature, 387.

Hampel, J., Keck, G., Peters, H.P., Pfennig, U. et al. (1997): Einstellungen zur Gentechnik. (Attitudes towards genetical engineering). Arbeitsbericht Nr. 87. Akademie für Technikfolgenabschätzung in Baden-Württemberg, Stuttgart.

Hampel, J. Renn, O. (1998): Kurzfassung der Ergebnisse des Verbundprojektes "Chancen und Risiken der Gentechnik aus der Sicht der Öffentlichkeit" (Summary report of the joint project on "Chances and risks of genetic engineering as viewed by the public"). Akademie der Technikfolgenabschätzung in Baden-Württemberg. Stuttgart, 52 p.

Hilliam, M. (1996): Functional foods: The Western consumer viewpoint. In: Nutrition Reviews 54, 189-194.

Hoban, Th.M. (1997): Consumer acceptance of biotechnology: An international perspective. Nature Biotechnology Vol 15, 232-235.

Gath, M., von Alvensleben, R. (1998): The potential effects of labelling GM foods on the consumer decisions - preliminary results of conjoint measurement experiments in Germany. AIR-CAT $5^{\text {th }}$ Plenary Meeting: Effective Communication and GM Foods. Vol 4, Nr 4, 18-28.

Lehner, S. (1998): Public perceptions of biotechnology and genetically modified food in Austria. AIR-CAT $5^{\text {th }}$ Plenary Meeting: Effective Communication and GM Foods. Vol 4, Nr 4, 29-43.

Miele, M., Parisi, V. (1998): Consumer concerns about animal welfare and the impact on food choice: Italy - Literature review. EU FAIR-CT98-3678, 24 p. 
Jonas, M.S., Beckmann, S.C. (1998): Functional foods: Consumer perceptions in Denmark and England. The Aarhus Business School, Working Paper 55.

Ophuis, O.P.A.M. (1994): Sensory evaluation of 'free range' and regular pork meat under different conditions of experience and awareness. Food Quality and Preference, 5, 173-178.

Plöger, M., Fricke, R., von Alvensleben, R. (1993): Analyse der Nachfrage nach BioProdukten. (Demand analysis for organic food). Reihe "Marketing in der Agrar- und Ernährungswirtschaft", Bd. 9, Wissenschaftsverlag Vauk Kiel, 212 p.

Potratz, B. (1999): Verbrauchereinstellungen zu Functional Food. (Consumer attitudes towards functional food). Lehrstuhl für Agrarmarketing, Institut für Agrarökonomie, Universität Kiel. Arbeitsbericht Nr. 16, 84 p.

Potter, D. (1991): Functional foods - A major opportunity for the food industry. In: Health \& Diet. Food Ingredients Europe: Conference Proceedings, 129-131.

Poulsen, J. (1999): Danish consumers' attitudes towards functional foods. The Aarhus Business School, Working Paper No 62.

Renken, Anette, (1997): Eine Analyse des Marktes für Hühnereier aus Verbrauchersicht. (An analysis of the egg market from the consumer's perspective). Diplomarbeit Kiel.

Röder, Elke (1997): Entwicklungstendenzen und Perspektiven der Naturkostbranche. (Developments and perspectives of the natural food trade). Landbauforschung, Sonderheft $175,177-181$.

Schifferstein, H.N.J., Oude Ophuis, P.A.M. (1998): Health-related determinants of organic food consumption in the Netherlands. Food Quality and Preference, 9, 119-133.

Scholderer, J. (1998): Gentechnik und Risikokommunikation: Die Sicht der Expertenöffentlichkeit. (Genetic engineering and risk communication: the view of the experts). 1. Aid-Forum Gen-Food: Nahrung der Zukunft am 9.6.1998 in Bonn.

Schütz, H., Wiedemann, P.M., Gray, P.C.R. (1999): Kognitive und interaktive Konstruktion von Risiko- und Nutzenurteilen bei gentechnisch hergestellten Produkten. (Cognitive and interactive construction of risk and benefit judgements about genetic engineered products). Projektbericht im Forschungsverbund "Chancen und Risiken der Gentechnik aus der Sicht der Öffentlichkeit" der Akademie für Technikfolgenabschätzung in Baden-Württemberg. Jülich, $52 \mathrm{p}$.

Sies, S., Mahlau, G. (1997): Das Image der Landwirtschaft - Ergebnisse von Assoziationstests. (The image of agriculture - results of association tests). Lehrstuhl für Agrarmarketing. Institut für Agrarökonomie, Universität Kiel. Arbeitsbericht Nr. 6, 71 p.

Will, P., Balling, R. (1988): Verbrauchereinstellungen und Einkaufsverhalten bei Rindfleisch. Ergebnisse einer Verbraucherbefragung. (Consumer attitudes and buying behaviour with respect to beef. Results of a consumer survey.) Arbeitsbericht Nr. 6 der Professur für landwirtschaftliche Marktlehre, Weihenstephan. 